\title{
Reduced Expression of Human Chemokine Genes RANTES and IP-10 in Hepatitis B Virus Mediated Cirrhosis of Liver
}

Gelli Veena Shravanthi \& Rathindra Mohan Mukherjee (Corresponding author)

\author{
Asian Healthcare Foundation \\ 6-3-661, Somajiguda, Hyderabad-500082, India \\ E-mail: rathinmukh@gmail.com \\ Padaki Nagaraja Rao \\ Asian Institute of Gastroenterology \\ 6-3-661, Somajiguda, Hyderabad-500082, India \\ Aparna Jakkampudi \& Panyala Balkumar Reddy \\ Asian Healthcare Foundation \\ 6-3-661, Somajiguda, Hyderabad-500082, India \\ Rajesh Gupta \& Duvvuru Nageshwar Reddy \\ Asian Institute of Gastroenterology \\ 6-3-661, Somajiguda, Hyderabad-500082, India
}

Received: April 17, 2012 Accepted: May 11, 2012

doi:10.5296/jbls.v3i1.2024 URL: http://dx.doi.org/10.5296/jbls.v3i1.2024

\begin{abstract}
Regulated upon Activation Normal T cell Expressed and Secreted (RANTES) and interferon gamma inducible protein 10 (IP-10), both chemokines are chemotactic for immunocompetent cells and play an important role in cell mediated antiviral defense. The objective of this work was to assess the expression pattern of RANTES and IP-10 genes in peripheral blood mononuclear cells (PBMCs) of hepatitis B virus (HBV) infected patients having various
\end{abstract}


disease severity. The study was performed on $79 \mathrm{HBV}$ infected patients grouped into acute, inactive carriers (IC), chronic (CHB), cirrhosis and hepatocellular carcinoma (HCC) plus 41 healthy voluntary blood donors as controls. Quantification of HBV surface antigen (HBsAg) was done by a sandwich enzyme linked immunosorbent assay (ELISA). Conventional and real time polymerase chain reaction (PCR) were used for genotyping and determination of HBV DNA load respectively. RANTES and IP-10 mRNA expressions were evaluated by reverse transcription PCR (RT-PCR) and densitometry. Results obtained show that RANTES expression reduced significantly $(\mathrm{p}<0.0001)$ in cirrhosis group in comparison to controls and remain unaltered in other disease categories. Reduction in IP-10 expression was significant $(\mathrm{p}=0.006)$ in patients of all disease categories than controls which was most evident in cirrhosis group $(\mathrm{p}<0.0001)$. No association was found between the expression level of chemokines with HBV genotypes, HBsAg and HBV DNA levels in sera.

It could be concluded that reduced expression of both the chemokines might be associated with lesser infiltration of immunocompetent cells to liver to avert further damage in cirrhosis.Serum level of both RANTES and IP-10 can be considered as prognostic marker of liver cirrhosis by validation studies.

Keywords: Chemokines, Gene expression, Peripheral blood mononuclear cells, Hepatitis B virus, Liver cirrhosis

\section{Introduction}

Hepatitis B virus (HBV) infection display variable outcome in infected subjects with relation to the severity of HBV induced liver diseases. While majority of adult individuals exposed to $\mathrm{HBV}$ are able to clear the virus after an acute phase of infection, about $5 \%$, being unable to control the virus, enter into the chronic phase of the disease. Such patients with chronic HBV infection (CHB) are more prone to develop severe liver diseases like cirrhosis and hepatocellular carcinoma (HCC) (Dienstag, 2008). In comparison to adults, neonates born from HBV infected mothers show increased rate of CHB infection, indicating the role of a functionally mature immune system. Since HBV is not considered as directly cytopathic to its host cell, it has been indicated that the prolonged host mounted immune response against the infected hepatocytes causes damage to HBV infected liver (Bertoletti, 2006).

At present, HBV is being considered as a stealth virus due to its ability to evade host innate immune mechanisms while viral clearance is brought about by functional adaptive immune responses (Wieland, 2005). In viral infection, certain innate immune cells are known to produce antiviral cytokines and chemokines which attract effector cells belonging to adaptive immune machinery. Study on the role of effective innate immune response in HBV infected subjects is further complicated because the patients are often diagnosed long after the onset of infection. Although HBV is not directly cytopathic to hepatocytes, it can mediate disease processes by inducing the infiltration of migratory immune cells (Chisari \& Tiollais, 1981) to the site of inflammation through chemokine signaling (Luster, 1998). Chemokines are chemotactic cytokines having highly conserved $\mathrm{NH}_{2}$-terminal cysteine residues. They help in the recruitment and activation of immune cells through their mobilization to inflammatory sites upon binding to certain $\mathrm{G}$ protein-coupled receptor subsets (Rossi, 2000). In hepatitis, 
interferon gamma ( IFN- $\gamma$ ) inducible protein 10 (IP-10, CXCL10) secreted from hepatocytes and liver sinusoidal endothelium can bind to CXCR3 receptors on NK cells, activated T cells, and dendritic cells exerting the chemoattractant effect on these cell types (Nishioji, 2001). RANTES (Regulated upon Activation Normal T cell Expressed and Secreted, CCL5) on the otherhand, is expressed by a number of other cell types than T cells alone, including epithelial cells and platelets that have been shown to play a role in anti viral immune responses (Crawford, 2011).

Induced expression of IP-10 mRNA has been shown using peripheral blood mononuclear cells (PBMCs) from subjects having chronic HBV infection (Wang, 2008) as well as in HBV mediated cirrhosis of liver (Wang, 2010). In contrast, induced expression of both RANTES and IP-10 genes have been shown to be associated with HBV clearance (Wieland, 2004). It has also been documented that $\mathrm{HBV}$ protein $\mathrm{X}(\mathrm{HBx})$ increases IP-10 expression in a dose-dependent manner through the modulation of NF-ksB pathway (Zhou, 2010). Despite the addition of new insight into the viral and host factors that determine pathogenesis and outcome of HBV infection, information regarding the level of expression of RANTES and IP-10 mRNA in various stages of HBV infection is still scanty. Based on this information, we attempted to assess the expression status of RANTES and IP-10 mRNAs in patients having acute and various categories of chronic HBV infection leading from mild to severe liver diseases.

\section{Materials and Methods}

\subsection{Patients}

Seventy nine HBsAg positive patients who attended the Asian Institute of Gastroenterology, Hyderabad, India during the period of October'2010 to April'2011 were included in this study. Based on clinical presentations, past history, imaging data, liver histopathology, Child-Pugh (CP) scores (Durand, 2005) antiHBc IgM/IgG status and as per AASLD practice guidelines (Lok, 2009; Bruix, 2005), patients were grouped into acute (AHB; n=29), inactive carriers (IC; $\mathrm{n}=13$ ), chronic (CHB; $\mathrm{n}=18$ ), cirrhosis (Cirr; $\mathrm{n}=11$ ) and hepatocellular carcinoma (HCC; $\mathrm{n}=8$ ) respectively. Patients coinfected with HIV, HAV, HCV, HDV, or HEV were excluded from the study. None of the patients had decompensated liver cirrhosis. A total of 41 healthy voluntary blood donors served as controls. Prior informed consents were taken from all the study subjects and the study protocol was approved by the institutional ethics committee.

\subsubsection{Serologic and Biochemical Parameters}

Commercial enzyme-linked immunosorbent assay (ELISA) kits (Amar-EASE, Taiwan) were used to evaluate the serum $\mathrm{HBeAg}$ and anti-HBe status of the patients as per kit protocol. Serum aspartate transferase (AST) and alanine transferase (ALT) levels were measured biochemically using an automated analyzer (Randox, Oceanside, CA, USA).

\subsubsection{HBV DNA Estimation and Genotyping}

Serum HBV DNA was extracted by the High Pure System Viral Nucleic Acid Kit (Roche Molecular Systems Inc, USA) as per given protocol. Extracted HBV DNA was further 
amplified and quantitated by Cobas ${ }^{\circledR}$ TaqMan ${ }^{\circledR} 48$ Analyzer (Roche Diagnostics, USA) using real time Cobas ${ }^{\circledR}$ TaqMan ${ }^{\circledR}$ HBV test kit (Roche Molecular System, USA). An in house nested polymerase chain reaction (PCR) assay involving type-specific primers (Mukherjee, 2009) followed by direct sequencing was employed to determine the genotypes of HBV.

\subsubsection{Quantitation of Serum HBsAg}

Quantitation of HBsAg (qHBsAg) level in patient's sera was estimated by a sandwich ELISA kit (Alpha Diagnostic International, San Antonio, TX) according to the kit protocol. For expression of data, $\mathrm{HBsAg}$ concentrations obtained in $\mathrm{ng} / \mathrm{mL}$ were converted to $\mathrm{IU} / \mathrm{mL}$, considering that $0.15 \mathrm{ng} / \mathrm{mL}$ of $\mathrm{HBsAg}$ is equivalent to $350 \mathrm{IU} / \mathrm{ml}$ as mentioned before (Biswas, 2003; Mukherjee, 2010).

\subsubsection{Isolation of Total RNA from PBMCs}

PBMCs were isolated from EDTA containing whole blood using histopaque-1077 (Sigma chemicals, USA) by recommended protocol. Total RNA was extracted from the isolated cells by Trizol (Life Technologies, USA) and the extracted RNA was dissolved in diethyl pyrocarbonate (DEPC)-treated water.

\subsubsection{Preparation of cDNA}

Extracted RNA was retrotranscribed to generate a common cDNA pool using random hexamers and MuLV-H reverse transcriptase (Fermantas Life Sciences, Germany). Prior to the reverse transcription reaction, $1 \mu \mathrm{g}$ of total RNA was treated with $1 \mathrm{U}$ of deoxyribonuclease (DNase I amplification grade, Gibco-BRL, USA) to remove any contaminating DNA.. In addition,control reactions were carried out without reverse transcriptase enzyme to further rule out the presence of DNA. RNA was reverse transcribed $\left(60 \mathrm{~min}\right.$ at $37{ }^{\circ} \mathrm{C}$ ) with $200 \mathrm{U}$ of MMuLV reverse transcriptase (Fermantas Life Sciences, Germany) in $20 \mu \mathrm{L}$ volume of $5 \mathrm{X}$ RT buffer $(250 \mathrm{mM}$ Tris- $\mathrm{HCl} \mathrm{pH} 8.3,375 \mathrm{mM} \mathrm{KCl}, 15$ $\mathrm{mM} \mathrm{MgCl}_{2}$ ) supplemented with $5 \mathrm{mM}$ dithiothreitol (DDT), $0.5 \mathrm{mM}$ deoxynucleoside triphosphates (dNTPs, Fermantas Life Sciences, Germany), 25 U ribonuclease inhibitor (Promega Corporation, Madison, WI, USA) and 200 ng random hexamers (Fermantas Life Sciences, Germany).

\subsubsection{Polymerase Chain Reaction (PCR) Amplification of RANTES and IP-10 mRNAs}

An aliquot of $5 \mu \mathrm{L}(0.3 \mu \mathrm{g})$ of the cDNA pool was used for PCR amplification in $50 \mu \mathrm{L}$ of 10 $\mathrm{X}$ buffer solution (100 mM Tris- $\mathrm{HCl} \mathrm{pH} 9.3,500 \mathrm{mM} \mathrm{KCl}, 1 \%$ Triton $\mathrm{X}-100)$ containing $0.08 \mathrm{mM}$ dNTPs, forward and reverse primers (40 $\mathrm{ng}$ each), $1.5 \mathrm{mM} \mathrm{MgCl} 2$ and $2 \mathrm{U}$ of Taq DNA polymerase (Fermantas Life Sciences, Germany). RANTES cDNA fragments were amplified by 29 cycles $\left(94^{\circ} \mathrm{C}-2 \mathrm{~min}, 55^{\circ} \mathrm{C}-2 \mathrm{~min} \& 72^{\circ} \mathrm{C}-2\right.$ min per step) with an initial denaturation at $95{ }^{\circ} \mathrm{C}$ for $5 \mathrm{~min}$ and final extension at $72^{\circ} \mathrm{C}$ for $10 \mathrm{~min}$ using forward and reverse primers (5'-3') d(ATA TTC CTC GGA CAC CAC AC) and d(CAC TCC AGC CTG GGG AAG GA) generating a product of 370bp (Conti, 2001). IP-10 cDNA fragments were amplified by 30 cycles $\left(94^{\circ} \mathrm{C}-1 \mathrm{~min}, 58^{\circ} \mathrm{C}-1.30 \mathrm{~min} \& 72^{\circ} \mathrm{C}-2 \mathrm{~min}\right.$ per step), having an initial 
denaturation at $95{ }^{\circ} \mathrm{C}$ for $5 \mathrm{~min}$ and final extension at $72^{\circ} \mathrm{C}$ for $3 \mathrm{~min}$ using up and downstream primers (5'-3') d(AGA GGA ACC TCC AGT CTC AGC), and d(CCT CTG TGT GGT CCA TCC TT) to yield a product of 228bp (Dajotoy, 2004). Beta-actin as house keeping gene was amplified by 30 cycles $\left(94^{\circ} \mathrm{C}, 55^{\circ} \mathrm{C} \& 72^{\circ} \mathrm{C} ; 1\right.$ min per step) using forward and reverse primers $\left(5^{\prime}-3^{\prime}\right) \mathrm{d}$ (TCT ACA ATG AGC TGC GTG TG) and d(GGT GAG GAT CTT CAT GAG GT) generating amplicon of $314 \mathrm{bp}$. Blank reactions without cDNA were included in all experiments as negative control. Each amplified product (10 $\mu 1)$ was subjected to $2 \%$ agarose gel electrophoresis $(100 \mathrm{~V}, 45 \mathrm{~min})$ along with a $100 \mathrm{bp}$ DNA ladder and visualized by UV fluorescence after staining with ethidium bromide.

Upon capturing the gel image by Bio-Capt (Vilber Lourmat, France), the integrated density of DNA band was evaluated by using the software Image J 1.42 (Broken Symmetry Software, USA) in respect to the known standard marker as a control with units nanogram per milliliters $(\mathrm{ng} / \mathrm{ml})$ and further normalized against the housekeeping gene beta actin used as internal control to define the expression of respective genes by the density of the band.

\section{Statistical Analyses}

Descriptive statistics (mean, median, standard deviations), Student's $t$-test, and Fisher's Exact tests were performed as and where applicable using GraphPad Prism software, USA. A value of $\mathrm{P}<0.05$ was considered statistically significant.

\section{Results}

\subsection{Patients}

All the patients were adults (Mean age $\pm \mathrm{SD}=36.67 \pm 13.2$ years), and consisted of 68 males and 11 females. The detailed demographic, biochemical and virological characteristics of 79 patients assigned to different disease categories are depicted in Table 1. Control subjects had a Mean \pm SD age of $29.4 \pm 10.1$ years and consisted of 23 males and 18 females. Of the 79 patients, 64 had HBV genotype D, 8 had genotype A and 7 were undetermined. Two patients in the AHB group and all 50 patients of remaining groups tested negative for $\mathrm{HBeAg}$ as well as were positive for anti $\mathrm{HBe}$ antibody.

\subsection{Expression Profile of RANTES and IP-10 Genes in Control and Patients}

No significant changes were observed in RANTES mRNA expression between the control and patient groups (Fig.1).The observed median value of RANTES in controls and patients were $134.9($ mean $\pm \mathrm{sd}=128.1 \pm 18.2)$ and $128.6($ mean $\pm \mathrm{sd}=119.6 \pm 108.3) \mathrm{ng} / \mathrm{ml}$ respectively. However, IP-10 gene expression was significantly reduced $(\mathrm{p}=0.006)$ in patients having median value of $90.6($ mean \pm sd $=123.1 \pm 128.6)$ than controls having median value of 190.2 $($ mean $\pm \mathrm{sd}=180.6 \pm 39.1) \mathrm{ng} / \mathrm{ml}$ respectively (Figure 1$)$.

\subsubsection{Comparative Expression of RANTES Gene in HBV Disease Categories}

RANTES expression showed non significant increment in AHB (median=155.6; mean $\pm \mathrm{sd}=140.9 \pm 104.4)$ but declined significantly $(\mathrm{p}=0.0001)$ in cirrhosis group (median=0; mean $\pm \mathrm{sd}=31.8 \pm 41.6$ ) in respect to controls (median=134.9; mean $\pm \mathrm{sd}=128.1 \pm 18.2$ ). No 
significant deviation was observed in any other disease categories in respect to controls (Figure 2).

\subsubsection{Comparative Expression of IP-10 Gene in HBV Disease Categories}

No significant alteration of IP-10 expression was noticed in the IC group when compared against the control values. Strikingly, in comparison to the expression value of IP-10 in controls (median $=190.2$; mean $\pm \mathrm{sd}=180.6 \pm 39.1$ ), the level of IP-10 mRNA was significantly reduced in cirrhosis group (median $=96.9 ;$ mean $\pm \mathrm{sd}=91.8 \pm 75.5 ; \mathrm{p}=0.0001$ ). The IP-10 expression also dropped, although less significantly in AHB (median=111.1; mean $\pm \mathrm{sd}=128.3 \pm 118.2 ; \mathrm{p}=0.01$ ) followed by $\mathrm{CHB}$ (median=73.8; mean $\pm \mathrm{sd}=121.0 \pm 139.3$; $\mathrm{p}=0.01$ ) and $\mathrm{HCC}$ groups (median=78.8; mean $\pm \mathrm{sd}=117.0 \pm 139.9 ; \mathrm{p}=0.01)$ respectively (Fgure 3).

4.2.3 Non Association of Serum HBsAg level, ALT Level and Viral Load with the Chemokine Gene Expression

Both RANTES and IP-10 gene expressions were comparatively analysed in patients having lower level of HBsAg (LHbsAg <4 $\log \mathrm{IU} / \mathrm{ml}, \mathrm{n}=30$ ) and those having higher HBsAg level (HHBsAg >4 $\log \mathrm{IU} / \mathrm{ml}, \mathrm{n}=72$ ). No significant change was found in any of the chemokine gene expression between patients having lower or higher HBsAg concentration. Similarly, non association of the expression level of both the genes was evident in patients having elevated $(>40 \mathrm{IU} / \mathrm{ml})$ or normal $(<40 \mathrm{IU} / \mathrm{ml})$ levels.

Of the 79 patients, 74 who had measurable serum HBV DNA were further divided into two categories based on their viral load i.e. low viral load (LVL, HBV DNA $<5$ log copies/ml) and high viral load (HBV DNA >5 log copies/ml) groups. No significant difference was observed in the expression profile of RANTES and IP-10 genes between the LVL and HVL groups.

\section{Discussion}

$\mathrm{HBV}$, being primarily a hepatotrophic virus, may intensify progressive liver injury leading to increased risk of developing liver cirrhosis and HCC (Ganem, 2004). It has been ascribed that a futile anti-viral immune response towards the virus is responsible for establishment of chronic HBV infection (Rehermann, 2005; Boonstra, 2008) although the exact mechanism by which HBV escapes immunity is still ambiguous. Conversely, HBV-associated liver damage is considered to be the consequence of a protracted cytolytic immune response generated against infected hepatocytes (Robek, 2004). One of the major role in this process is thought to be the migration of immune cells to infected liver under the influence of chemokine signaling. While RANTES is chemotactic for eosinophils, basophils, T cells, and induces the proliferation and activation of certain natural-killer (NK) cells (Maghazachi, 1996), chemoattraction activity of IP-10 was observed on monocytes, macrophages, T cells, NK cells, and dendritic cells respectively (Dufour, 2002). The intrahepatic production of chemokines is supposed to be associated with the conscription of antigenically nonspecific immunocompetent cells into the liver which can augment the severity of cirrhosis initiated by CTLs having defined antigen specificity. 
The major pathway for viral clearance in liver has been ascribed to the noncytopathic antiviral mechanism of CTLs than killing of HBV infected hepatocytes by CTLs through direct contact. This noncytopathic viral clearance occur by inhibition of replication and expression of HBV genome through intrahepatic secretion of IFN- $\gamma$ (Wieland, 2005; Robek, 2004). Based on this information, we tried to assess the mRNA expression patterns of two IFN- $\gamma$ inducible chemokines i.e. RANTES and IP-10 in clinically defined HBV disease categories.

In our study, the mRNA expression of IP-10 but not RANTES was found to be significantly reduced in total HBV infected patients than the healthy controls. A subtle, though, nonsignificant increase in mRNA expression of RANTES was seen in AHB group than controls but not encountered in IC, CHB and HCC groups. Perceptibly, compared to controls, the RANTES expression was significantly downregulated in cirrhosis group. As observed against controls, unlike RANTES expression, a significant decline in the IP-10 mRNA expression was noticeable in all the HBV disease categories, which was also most evident in cirrhosis group.

In contrast, Zhang et al (2009) reported significant elevation of serum RANTES level in CHB patients which was independent of $\mathrm{HBeAg}$ positivity or HBV DNA concentration. Wang et al (2008; 2010) reported significant increase in serum level and mRNA expression of IP-10 in PBMCs of $\mathrm{CHB}$ and $\mathrm{HBV}$ mediated cirrhosis patients along with increased level of HBV DNA in such patients. Regarding the involvement of viral components with the expression pattern of RANTES and IP-10, our data are in contrast to those of Wang et al (2010) but at par with those of Zhang et al (2009), since we did not observe any association of mRNA expression pattern of either of the chemokines with the level of serum HBsAg or HBV DNA in our study subjects. This finding seems not to be unlikely on the basis of reported involvement of HBV X protein (HBX) regulating the expression of IP-10 through activation of NF- $\kappa$ B pathway (Zhou, 2010).

The observed non induction of RANTES and suppression of IP-10 mRNAs in our HBV infected subjects can be advantageous for the virus to persist and to establish chronic infection. Keeping in mind the reported findings of immune stimulatory effects of HBV towards other cells of the immune system, such as Kupffer cells in liver (Hosel, 2009), the significant drop in the mRNA expression of both RANTES and IP-10 as observed in our group of cirrhotic subjects might have insinuations in promoting lesser recruitment of immunocompetent cells from peripheral pool to liver to avert further damage. This conjecture can be conjured up to our earlier finding of significant suppression of CD8 T cells in CHB subjects without any numerical increment in the T helper (CD4) or NK cell populations (Mukherjee, 2010). Of note, Crawford et al (2011) reported a significant reduction in CD8 T cell numbers and function in the absence of RANTES in chronic viral infection while the CD4 $\mathrm{T}$ cells remain unaffected in such situation.

To the best of our knowledge, this is the first study where the mRNA expression of two major cell mobilizing chemokines i.e. RANTES and IP-10 were assessed in patients belonging to clinically defined disease categories in HBV infection. However, the present study has 
limitations. These include small number of cirrhotic subjects, stages of liver damage were not biopsy proven and the serum level of both the chemokines were not measured.

Despite the limitations, our findings raise the possibility to undertake further studies involving larger cohorts of cirrhotics of both HBV and non viral etiology. Such studies will help to clarify the potentiality of using serum/plasma level of RANTES and IP-10 as putative biomarker for liver cirrhosis in patients from Indian subcontinent.

\section{Conclusions}

Our study in human patients with various categories of HBV infection showed significant reduction in mRNA expression of RANTES and IP-10, most evidently in HBV mediated cirrhosis of liver. Our findings raises the caveat that immune cell migration from peripheral blood to liver might have less important role than the resident immune cells in liver to cause further damage in HBV mediated cirrhosis of liver.

\section{References}

Bertoletti, A., \& Gehring, A. J. (2006). The immune response during hepatitis B virus infection. J Gen Virol, 87, 1439-1449.

Biswas, R., Tabor, E., Hsia, C. C., et al. (2003). Comparative sensitivity of HBV NATs and HBsAg assays for detection of acute HBV infection. Transfusion, 43, 788-798.

Boonstra, A., Woltman, A. M., \& Janssen, H. L. (2008). Immunology of hepatitis B and hepatitis C virus infections. Best Pract Res Clin Gastroenterol, 22, 1049-1061.

Bruix, J., \& Sherman, M. (2005). Management of hepatocellular carcinoma. Hepatology, 42, 1208-1236.

Chisari, F. V., \& Ferrari, C. (1995). Hepatitis B virus immunopathogenesis. Annu Rev Immunol, 13, 29-60.

Conti, P., Barbacane, R. C., Feliciani,C., \& Reale, M. (2001). Expression and secretion of RANTES by human peripheral blood CD4+ cells are dependent on the presence of monocytes. Annals of Clinical \& Laboratory Science, 31, 75-84.

Crawford, A., Angelosanto, J. M., Nadwodny, K. L., Blackburn, S. D., \& Wherr, E. J. (2011). A role for the chemokine RANTES in regulating CD8 $\mathrm{T}$ cell responses during chronic viral infection. PLoS Pathogens, 7, e1002098.

Dajotoy, T., Andersson, P., Bjartell, A., Lofdahl, C. G., Tapper, H., \& Egesten, A. (2004). Human eosinophils produce the $\mathrm{T}$ cell-attracting chemokines MIG and IP-10 upon stimulation with IFN- $\gamma$. J Leukocyte Biol, 76, 685-691.

Dienstag, J. L. (2008). Hepatitis B virus infection. N Engl J Med, 359, 1486-1500.

Dufour, J. H., Dziejman, M., Liu, M. T., Leung, J. H, Lane, T. E., \& Luster, A. D. (2002). IFN-gamma-inducible protein 10 (IP-10; CXCL10)-deficient mice reveal a role for IP-10 in effector T cell generation and trafficking. J Immunol, 168, 3195-3204. 
Durand, F., \& Valla, D. (2005). Assessment of the prognosis of cirrhosis: Child-Pugh versus MELD. J Hepatol, 42, s100-s107.

Ganem, D., \& Prince, A. M. (2004). Hepatitis B virus infection-natural history and clinical consequences. N Engl J Med, 350, 1118-1129.

Hosel, M.,Quasdorff, M.,Wiegmann, K.,Webb, D.,Zedler, U., et al. (2009). Not interferon, but interleukin-6 controls early gene expression in hepatitis B virus infection. Hepatology, 50, 1773-1782.

Lok, A.S.F., \& McMahon, B.J. (2009). Chronic hepatitis B: Update 2009. Hepatology, 50, $1-36$.

Luster, A.D. (1998). Chemokines - Chemotactic cytokines that mediate inflammation. $N$ Eng $J$ Med, 338, 436-445.

Maghazachi, A.A., Al-Aoukaty, A., \& Schall, T.J. (1996). CC chemokines induce the generation of killer cells from CD56+ cells. Eur J Immunol, 26, 315-319.

Mukherjee, R.M., Balkumar Reddy, P., Sasikala, M., et al. (2009). Identification of genotype B among Hepatitis B virus-infected patients in hyderabad, India. Ann Hepatol, 8, 269-70.

Mukherjee, R.M., Balkumar Reddy, P., Arava, J., et al. (2010). Relationship between serum HBsAg level, HBV DNA level, and peripheral immune cells in patients with chronic hepatitis B virus infection. Hep Med: Evidence and Research, 2, 157-162.

Nishioji, K., Okanoue, T., Itoh, Y., Narumi, S., Sakamoto, M., Nakamura, H., Morita, A., \& Kashima, K. (2001). Increase of chemokine interferon-inducible protein-10 (IP-10) in the serum of patients with autoimmune liver diseases and increase of its mRNA expression in hepatocytes. Clin Exp. Immunol, 123, 271-279.

Rehermann, B., \& Nascimbeni, M. (2005). Immunology of hepatitis B virus and hepatitis C virus infection. Nat Rev Immunol, 5, 215-229.

Robek, M.D., Boyd, B.S.,Wieland, S.F., \& Chisari, F.V. (2004). Signal transduction pathways that inhibit hepatitis B virus replication. Proc Natl Acad Sci USA, 101, 1743-1747.

Rossi, D., \& Zlotnik, A. (2000). The biology of chemokines and their receptors. Annu Rev Immunol, 18, 217-242.

Tiollais, P., Charnay, P., \& Vyas, G. N. (1981). Biology of hepatitis B virus. Science, 213, 406-411.

Wang, J., Zhao, J.H., Wang, P.P., \& Xiang, G.J. (2008). Expression of CXC chemokine IP-10 in patients with chronic hepatitis B. Hepatobiliary Pancreat Dis Int, 7, 45-50.

Wang, J., Wang, P.P., Xiang, G.J., \& Hu, X.B. (2010). Relationship between the expression of IP-10 and IP-10 mRNA in peripheral blood and HBV DNA level in patients with cirrhosis. Hepatobiliary Pancreat Dis Int, 9, 280-286. 


\section{IIMacrothink}

Wieland, S., Thimme, R., Purcell, R.H., \& Chisari, F.V. (2004). Genomic analysis of the host response to hepatitis B virus infection. Proc Natl Acad Sci USA, 101, 6669-6674.

Wieland, S.F., \& Chisari, F.V. (2005). Stealth and cunning: Hepatitis B and Hepatitis C viruses. J Virol, 79, 9369-9380.

Zhang, K., Xu, Q.H., Chen, L.B., Shu, X., Chen, N., \& Li, G. (2009). Correlation of serum chemokine RANTES level with serum biochemical indices, HBeAg and HBV DNA load in patients with chronic hepatitis B. Chinese J Exp Clin Virol, 23, 188-90.

Zhou, Y., Wang, S., Ma, J.W., Lei, Z., Zhu, H.F., Lei, P., et al. (2010). Hepatitis B virus protein X-induced expression of the CXC chemokine IP-10 is mediated through activation of NF-ķB and increases migration of leukocytes. J Biol Chem, 285, 12159-12168.

\section{Glossary}

- AHB : Acute hepatitis B.

- $\quad$ ALT : Alanine Transferase.

- $\quad$ AST : Aspartate transferase.

- CHB : Chronic hepatitis B.

- CTL : Cytotoxic T lymphocytes.

- ELISA : Enzyme linked immunosorbent assay.

- HBeAg : Hepatitis B e antigen.

- $\quad$ HBV ; Hepatitis B virus.

- HBV DNA : Hepatitis B virus deoxyribonucleic acid.

- HCC : Hepatocellular carcinoma.

- HBsAg : Hepatitis B surface antigen.

- HHBsAg : High hepatitis B surface antigen.

- HVL : High viral load.

- $\quad$ IC : Inactive carriers.

- IP-10 : Interferon inducible protein 10.

- LHBsAg : Low hepatitis B surface antigen.

- $\quad$ LVL : Low viral load.

- PBMC : Peripheral blood mononuclear cell.

- PCR : Polymerase chain reaction. 


\section{Macrothink}

- $\quad$ RANTES : Regulated upon Activation Normal T cell Expressed and Secreted.

- $\quad$ RT-PCR : Reverse transcription-polymerase chain reaction

Table 1. Baseline characteristics of the patients

\begin{tabular}{|l|l|l|l|l|l|}
\hline Parameters & \multicolumn{5}{|c|}{ Disease Categories (n=79) } \\
\hline & AHB(n=29) & IC (n=13) & CHB(n=18) & Cirrhosis(n=11) & HCC (n=8) \\
\hline $\begin{array}{l}\text { Age } \\
(\text { Mean } \pm \text { SD) }\end{array}$ & $35.8 \pm 13.1$ & $34.5 \pm 11.2$ & $34.7 \pm 10.5$ & $46.3 \pm 12.8$ & $48.9 \pm 10.7$ \\
\hline Sex(M:F) & $26: 3$ & $11: 2$ & $14: 4$ & $9: 2$ & $8: 0$ \\
\hline ALT(IU/L-Mean \pm SD) & $908 \pm 114.8$ & $31.6 \pm 11.7$ & $68.7 \pm 23.8$ & $98.7 \pm 34.7$ & $89.4 \pm 33.0$ \\
\hline $\begin{array}{l}\text { HBVDNA(log copies/ml- } \\
\text { Mean } \pm \text { SD, })\end{array}$ & $5.17 \pm 1.75$ & $2.59 \pm 1.11$ & $6.44 \pm 1.83$ & $4.95 \pm 2.23$ & $6.78 \pm 2.21$ \\
\hline $\begin{array}{l}\text { Mean HBs Ag } \\
\text { (Log IU/ml- Mean } \pm \text { SD) }\end{array}$ & $4.89 \pm 0.81$ & $3.17 \pm 0.57$ & $4.22 \pm 0.76$ & $4.43 \pm 0.33$ & $4.35 \pm 0.11$ \\
\hline
\end{tabular}

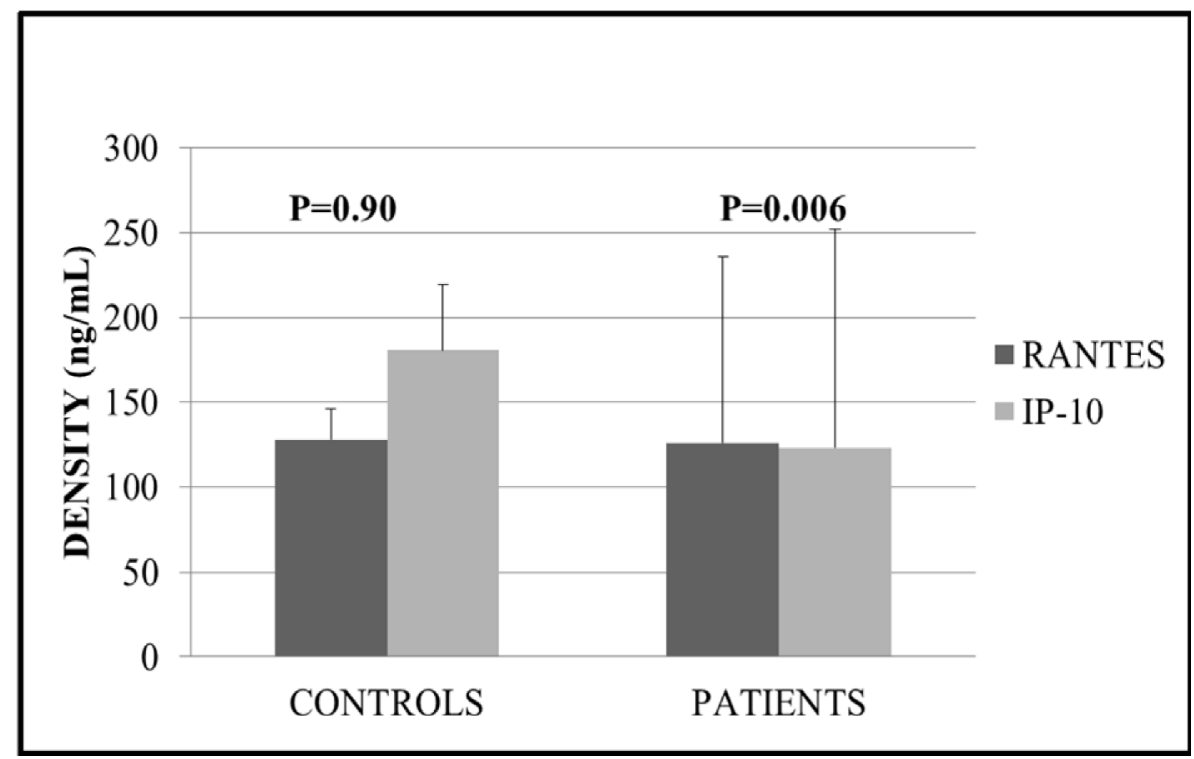

Figure 1. Differential expression profile of RANTES and IP-10 mRNA in control and patient groups (vertical bar-SD). 


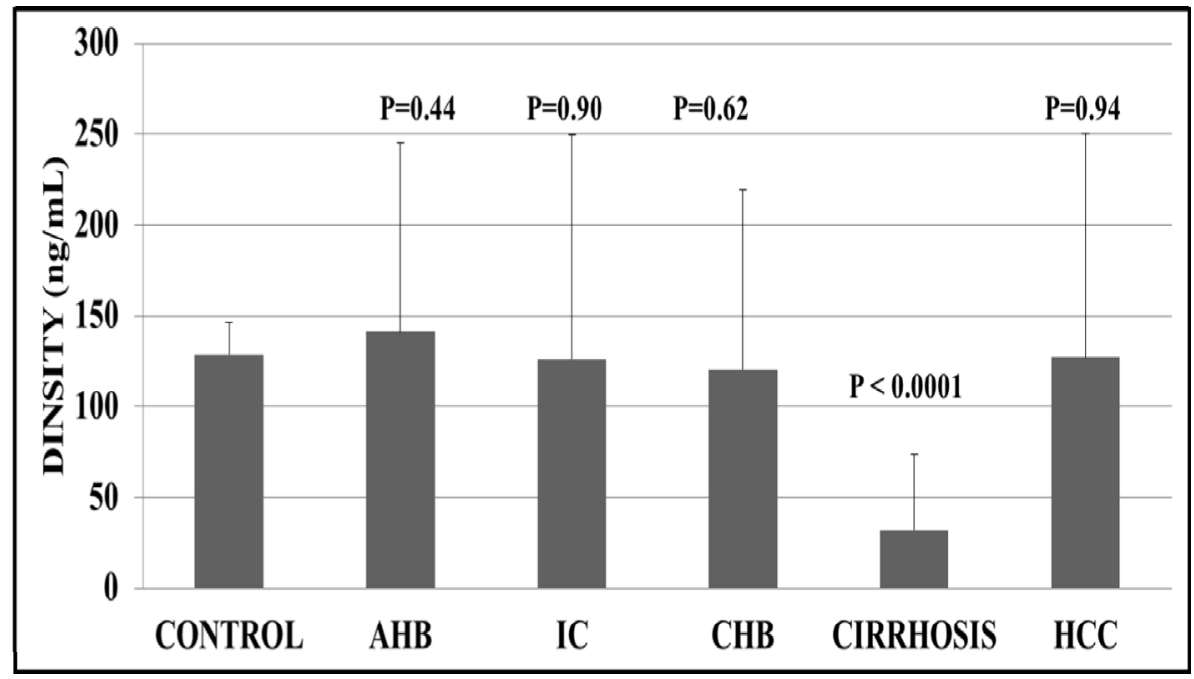

Figure 2. Comparative expression profile of RANTES mRNA in control and HBV disease categories (AHB-Acute hepatitis B;IC-Inactive carriers;CHB-Chronic hepatitis $\mathrm{B} ; \mathrm{HCC}-\mathrm{Hepatocellular}$ carcinoma; vertical bar-SD).

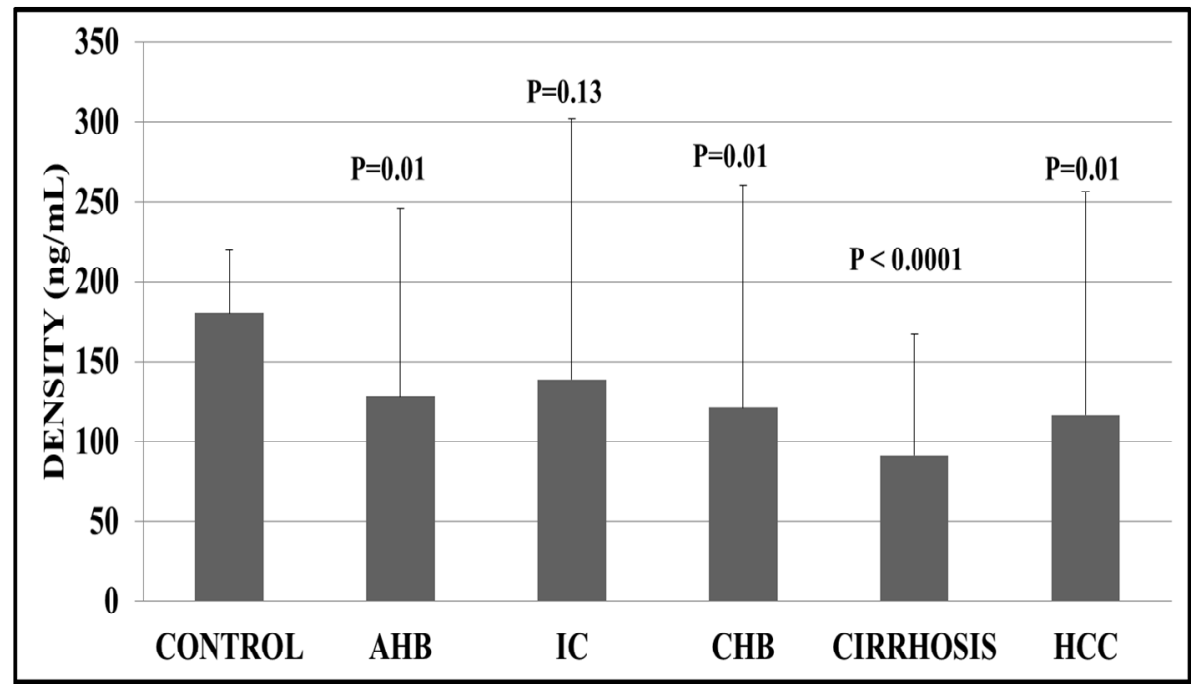

Figure 3. Suppression of IP-10 mRNA in HBV disease groups (AHB-Acute hepatitis B;IC-Inactive carriers;CHB-Chronic hepatitis B;HCC-Hepatocellular carcinoma;vertical bar-SD).

\section{Copyright Disclaimer}

Copyright reserved by the author(s).

This article is an open-access article distributed under the terms and conditions of the Creative Commons Attribution license (http://creativecommons.org/licenses/by/3.0/). 